\title{
ПОЛІЩЯ ЯК ЧАСТИНА ГРОМАДИ. ФОРМИ КОМУНІКАЦІї
}

\section{НОВІЧЕНКО Андрій - доктор філософї, докторант Харківського національного університету внутрішніх справ}

DOI 10.32782/NP.2021.4.2

Однією з головних умов успішного бункиіонування будь-якоӥ соціальної системи, у тому числі $і$ правоохоронної, є об'єднання зусиль $i$ можливостей ӥ складових частин для досягнення загальних иілей. Будь-яка держава має излісну систему, що володіє безліччю інтеграиійних властивостей. Будучи покликаною забезпечити певну урегульованість $i$ впорядкованість соиіальних відносин, держава сама має володіти якістю єдності, складатися з сукупності державних органів у певній залежності складових компонентів з властивими їй внутрішніми (системними) $i$ зовнішніми (бункиіональними зв'язками), взаємозв'язками $i$ взаємодіями. Взаємодія як прояв діяльності цілісності будь-якої системи органічно притаманне їй, у силу чого носить об'єктивний характер.

Вивчаючи історію та сучасний стан участі правоохоронних органів як частини громади можна констатувати, що одним iз найважливіших інструментів правоохоронної діяльності є взаємодія з населенням. Мета правоохоронних органів зосереджується на контролі конкретної території, протидї кримінальним правопорушенням та забезпечення охорони правопорядку, для реалізацї поставлених иілей необхідно враховувати потреби громадян. Така постановка питання потребує індивідуального підходу, з одного боку, а з іншого - ие готовність громадськості взяти на себе частину відповідальності, спрямованості на покращення загальної якості життя. Таким чином, породжується парт- нерство між полічією та громадсъкістю, яке будується на довірі з обох сторін.

Ключові слова: полічія, партнерство, суспільство, взаємодія, громадськість, правопорушення, протидія.

\section{Постановка проблеми}

Основним завданням встановлення партнерських відносин поліції і суспільства, при яких усі поліцейські структури, всі державні структури і населення активно співпрацюють у вирішенні територіальних проблем, поліцейська робота з громадянами за місцем проживання зосереджується на зміні процесу проведення своїх функцій, але не основних цілей поліцейської діяльності. Такі цілі, як і раніше, передбачають забезпечення громадського спокою і правопорядку; захист основних прав і свобод особи - особливо життя; запобігання та розслідування кримінальних правопорушень; надання сприяння і послуг суспільству з метою зниження рівня страху перед злочинністю, можливістю отримання тілесних ушкоджень і виникнення соціально-побутових порушень, а також з метою попередження соціального занепаду районів проживання. Разом з тим, партнерство поліції і суспільства дійсно забезпечує більш ефективну і дієву стратегію досягнення цих цілей. Основною передумовою партнерства між поліцією і суспільством є нагальна необхідність підвищення рівня залученості суспільства у діяльність забезпечення безпеки та громадського порядку, а також вирішення проблеми злочинності в 
місцях проживання громадян, оскільки ця задача не може бути вирішена силами однієі лише поліції.

\section{Мета статті}

Ця стаття присвячена визначенню місця поліції як частини громади. Визначення та аналізу форм комунікації правоохоронних органів з суспільством в аспекті партнерства, метою якого $є$ протидія кримінальним правопорушенням та забезпечення охорони правопорядку.

\section{Стан дослідження проблеми}

Правові та функціональні аспекти взаємодії правоохоронних органів та суспільства досліджувані у працях таких учених, як О.М. Бандурка, О.І. Беспалова, Т.З. Гарасимів, В.І.Борденюк, В.В. Кадала, М.В. Корнієнко, М.Я. Завальний, А.А. Прокопенко, Н.Р.Нижник та інших. Досить обширно розглянуто та проаналізовано вченими правові та функціональні аспекти взаємовідносин поліції з громадським суспільством. На теперішній час залишається недостатньо дослідженим питання щодо визначення місця правоохоронних органів як частини громади та їх форми комунікації.

\section{Наукова новизна дослідження}

У сучасних непростих соціально - економічних умовах, складної криміногенної обстановки органи Національної поліції, як ніколи, гостро потребують партнерських відносин з громадськістю з метою підвищення рівня протидії кримінальним правопорушенням та забезпечення охорони правопорядку. Такі взаємини успішно будуть реалізовані лише при повній довірі з обох сторін.

На сьогодні, враховуючи дані опитування громадян, рівень довіри з боку суспільства до правоохоронних органів низький.У таких умовах основні завдання працівників поліції повністю не можуть бути реалізовані, хоча завдання співробітників поліції і громади, направлені на протидію кримінальним правопорушенням та охороні правопорядку співпадають. Поліція є складовою частиною суспільства, і їх невід'ємно об’єднує спільна мета - протидія злочинності та забезпечення охорони правопорядку.

\section{Виклад основного матеріалу}

Будь-яка держава - це формальний інститут, який є формою організації політичної та соціальної спільноти. Відносини в суспільстві завжди повинні бути під контролем відповідних органів, такі відносини можуть виходити з під контролю і в певній мірі стають протиправними. Виходячи з вищевикладеного, для врегулювання, запобігання та охорони суспільства та державного устрою виникає необхідність у створенні спеціальних органів, які 6 виконували ці функції. На сучасному етапі розвитку України, згідно 3 ч. 1 ст. 1 Закону України «Про Національну поліцію», такі функції виконує Національна поліція України (поліція) центральний орган виконавчої влади, який служить суспільству шляхом забезпечення охорони прав і свобод людини, протидії злочинності, підтримання публічної безпеки i порядку [1].

Поліцейські функції завжди притаманні будь-якій державі. Але це не означає, що держава завжди має у своєму механізмі постійні, спеціалізовані установи, що реалізують поліцейські функції. У період середини XVII - початку XVIII століття значна частина українських земель входила до складу Російської імперії, на українських землях діяла тоталітарна імперська політика російського царизму. До початку Петровських реформ XVIII ст. поліцейські завдання були покладені на різні державні установи. Підтримка охорони громадського порядку здійснювалося стрільцями і в подальшому підрозділами професійної армії. Охорона громадського порядку та боротьба зі злочинністю не була достатньо складною і актуальною для Російської імперії XVII - початку XVIII ст. Періодичні стихійні бунти, міські повстання, викликані соціально-економічними причинами, закінчувалися тим, що задовольнялися вимоги повсталих або ж вони «придушувалися» стрільцями і дворянським ополченням. Переважна частина населення жила у сільській місцевості і перебувала під соціальним, адміністративним контролем громади. Поведінка підданих російського царя регулювалося традиціями, обрядами, морально-релігійними нормами. 


\section{Теорія, історія держави і права, конституційне право}

Селянська війна під керівництвом Разіна і польсько-шведська інтервенція на початку XVII ст. обумовили створення твердої влади для забезпечення порядку на місцях. За розпису міст і повітів 1625 р. відомо, що в 146 містах з повітами вже були призначені воєводи. Воєвода став основною ланкою місцевого управління. Претенденти на місце воєвод - бояри, дворяни і діти боярські - подавали на ім'я царя чолобитну, у якій просили призначити на воєводство, щоб «погодувати». Однак офіційно воєвода за свою службу отримував помісні грошові оклади. Воєвода призначався розрядним наказом, затверджувався царем і Боярської думою і підкорявся тому наказу, у веденні якого знаходло це місто $з$ повітом.

У XVII ст. у Російській імперії, до складу якої входила і частина українських земель, продовжували існувати обидві форми «самоврядування» - губна і земська. Справами кожного округу (губи) відав губний староста, його помічниками були цілувальники [2, c. 186]. Губного старосту вільне населення округу обирало з дворян і боярських дітей, цілувальники вибиралися з чорносошну селян або посадських. Земські органи «самоврядування» - земські старости і цілувальники - вибиралися чорносошними селянами і посадськими людьми на сходах у містах, станах, волостях і цвинтарях. Ці органи відали розкладкою податей між населенням, наглядали за тим, щоб воно не ухилялося від несення тягла. Земські органи здійснювали і деякі поліцейські функції: стежили за збереженням спокою, дотриманням митних зборів тощо. У поліцейському відношенні земські органи були повністю підпорядковані воєводам.

Новий історичний період взаємодії інститутів громадськості 3 правоохоронними органами розпочався із затвердженням у 1837 році Миколою I (тогочасним імператором Російської імперії) ряду законодавчо-нормативних актів, що стосуються реорганізації органів місцевого самоврядування, створення державних структур земської поліції, введення конкретних посад в органах поліції (сотські, десятські) 3 метою забезпечення охорони громадського правопорядку та виконання наказів станового пристава [3].

Таким чином, за часи Російської імперії на українських землях партнерство між суспільством та правоохоронними органами в повній мірі не діяло. Правоохоронні органи тих часів займали головне місце серед суспільства, але взаємовідносини між громадськістю та поліцією того часу гальмувались, тому можна констатувати практичну відсутність взаємин між ними.

Розвиток сучасних тенденцій громадянської активності, ускладнення і зміна соціального середовища, у тому числі і в тій іï частині, яка генерує девіантна поведінка, супроводжується зростаючими вимогами до змістовної діяльності правоохоронних органів, змушує їх адаптуватися. У зв'язку з цим актуальною є активізація, розширення, переклад на новий рівень взаємодії органів поліції 3 інститутами громадянського суспільства. Розвиток таких тенденцій породжує переосмислення сучасних форм взаємодії, однією 3 яких є соціальне партнерство.

Дослідження сутності соціального партнерства передбачає отримання чіткого уявлення про те, що слід розуміти під цим терміном. У словниках термін «партнер» (від франц. le partenaire) - означає компаньйон, співучасник, актор, агент, «учасник спільної діяльності» [4, с. 357]. У соціологічному словнику підкреслюється, що це один 3 рівноправних учасників спільної діяльності (у грі, танці, бізнесі, на сцені тощо) [5]. Енциклопедичний соціологічний словник під редакцією Г.В. Осипова визначає «партнерство» як спільну діяльність, засновану на рівних правах і обов'язках, спрямовану на досягнення спільної мети [6, с. 186].

В узагальненому розумінні поняття «соціальне партнерство» характеризує широкий спектр активних соціальних взаємодій, спрямованих на задоволення деяких загальних інтересів і потреб за умови відмови від конфронтації (протиборства) і обрання соціальними суб’єктами стратегії досягнення оптимального компромісу та вироблення взаємовигідного угоди.

Інакше кажучи, партнерство між поліцією та громадськістю сприяє перетворенню суспільства, що має здійснюватися мирним 
шляхом і на основі співпраці з правоохоронними органами, яке має на меті підвищення рівня протидії кримінальним правопорушенням та забезпечення охорони правопорядку. А отже, як пріоритетні, постають питання якості та безпеки життя, самореалізації індивіда, формуються нові критерії соціального благополуччя. Зміни, що відбуваються, породжують розвиток соціально орієнтованої діяльності держави. Акцент зміщується в бік надання послуг населенню, задоволеності громадян і тих факторів, які безпосередньо відображають потреби суспільства. На зміну домінуючих взаємин держави над суспільством приходить концепція соціального партнерства.

Найважливішою функцією держави $є$ правоохоронна функція. В умовах правової держави правоохоронна функція є одним 3 основних напрямків діяльності держави щодо створення певних умов для гідного і безпечного існування особи, суспільства і держави, взаємодії між ними. Взаємодія громадянського суспільства та держави при реалізації правоохоронної функції здатне зблизити населення і владу, вирішити багато протиріч у соціальній та державно-правовій сферах. Тільки тісна взаємодія держави і громадянського суспільства в особі його інститутів можуть дозволити ефективне здійснення правоохоронної функції держави на території України в сучасних умовах.

Механізм партнерської взаємодії інститутів громадянського суспільства і держави у сфері реалізації правоохоронної функції передбачає наявність:

1) суб’єктної складової (визначення кола суб'єктів, що беруть участь у реалізації правоохоронної функції держави);

2) нормативної складової - нормативно-правової бази - основи регулювання взаємовідносин інститутів держави і громадянського суспільства;

3) функціональної складової - напрямків спільної діяльності і організаційних форм взаємодії держави та громадянського суспільства (наприклад: проведення громадянських форумів, створення громадських палат, здійснення контролю).
В основу партнерської моделі взаємовідносин суб'єктів здійснення правоохоронної функції держави - поліції та інститутів громадянського суспільства належить довіра громадян до державних органів.

Спираючись на співпрацю з інститутами громадянського суспільства, поліція здійснює правоохоронну діяльність, виконуючи своє головне призначення - служити суспільству. Основною передумовою партнерства поліції і громадянського суспільства є залученість громадян, спрямована на гарантування безпеки та громадського порядку. При партнерській моделі населення не тільки безпосередньо бере участь в охороні правопорядку, але і своєчасно інформує поліцію про всі ситуації, які можуть йому загрожувати, що, у свою чергу, підвищує результативність діяльності поліції. Поліція має бути доступною для населення, знати населення на підвідомчій території та бути відомою йому, відгукуватися на потреби населення, прислухатися до проблем громадян, залучати і мобілізовувати населення, звітувати перед громадою у своїх діях і досягнутих результатах. Ефективність здійснення правоохоронної функції держави багато в чому залежить від взаємодії поліції і суспільства.

Партнерська модель взаємовідносин органів державної влади та інститутів громадянського суспільства у сфері реалізації правоохоронної функції отримала своє відображення у багатьох міжнародних і національних нормативно-правових актах. Кодекс поведінки посадових осіб з підтримання правопорядку [7], у якому закріплюються вимоги до поведінки і функцій працівників поліції, підкреслює взаємозв'язок моральних і правових регуляторів у системі соціальних норм, покладених в основу професійної діяльності поліції. Необхідність захисту прав і свобод людини, виключення свавіляя з боку посадових осіб в їх взаємовідносинах з громадянами та порушення закону зумовили пред'явлення високих вимог до осіб, які підтримують правопорядок.

Важливим документом, що встановлює основні міжнародні правила діяльності поліцейських із забезпечення прав людини і основних свобод, є Декларація про поліцію [8],у якій відзначається, що поліція відіграє жит- 


\section{Теорія, історія держави і права, конституційне право}

тєво важливу роль для держави і членів суспільства; умови, у яких змушена діяти поліція, пов’язані з ризиком для співробітників, і відсутність визначених правил поведінки ускладнює виконання співробітниками своїх обов’язків. Закріплені в «Декларації про поліцію» етичні норми, яким повинен слідувати поліцейський, повинні сприяти тісній співпраці поліції та суспільства.

Закон України «Про Національну поліцію» в ст. 11 закріплює, що діяльність поліції здійснюється в тісній співпраці та взаємодії з населенням, територіальними громадами та громадськими об'єднаннями на засадах партнерства і спрямована на задоволення їхніх потреб [1]. Закон України «Про участь громадян в охороні громадського порядку і державного кордону» в ст. 1 регламентує, що громадяни України відповідно до Конституції України мають право створювати в установленому цим Законом порядку громадські об'єднання для участі в охороні громадського порядку і державного кордону, сприяння органам місцевого самоврядування, правоохоронним органам, Державній прикордонній службі України та органам виконавчої влади, а також посадовим особам у запобіганні та припиненні адміністративних і кримінальних правопорушень, захисті життя та здоров'я громадян, інтересів суспільства і держави від протиправних посягань, а також у рятуванні людей і майна під час стихійного лиха та інших надзвичайних обставин [9].

Ці Закони визначили перспективи розвитку взаємовідносин поліції 3 громадянським суспільством. Вони містить ряд концептуальних ідей, у числі яких: встановлення партнерської моделі взаємовідносин поліції і суспільства; контроль громадянського суспільства за діяльністю поліції; закріплення нового іміджу співробітників правоохоронних органів. Партнерська модель характеризується посиленням співпраці обох сторін. Перспективи такого посилення полягають у законодавчому визначенні прав і обов'язків, закріпленні правового статусу поліцейського при вирішенні питань взаємодії, звільнення відомства від невластивих йому або дублюючих функцій. Інакше кажучи, ці Закони відображають суть партнер- ської моделі відносин поліції і суспільства: відкритість, публічність, довіру, взаємодоповнюваність, паритетне співробітництво.

Крім того, Закон України «Про участь громадян в охороні громадського порядку і державного кордону» створює правові умови добровільної участі громадян України в охороні громадського порядку - надання громадянами допомоги органам поліції 3 метою захисту життя, здоров'я, честі та гідності людини, власності, інтересів суспільства і держави від злочинних та інших протиправних посягань.

Згідно зі ст. 2, Закон України «Про місцеве самоврядування в Україні» закріплює те, що місцеве самоврядування в Україні це гарантоване державою право та реальна здатність територіальної громади - жителів села чи добровільного об'єднання у сільську громаду жителів кількох сіл, селища, міста самостійно або під відповідальність органів та посадових осіб місцевого самоврядування вирішувати питання місцевого значення в межах Конституції і законів України [10]. Крім того, цей Закон передбачає права, принципи, процедуру проведення зборів органів місцевого самоврядування тощо. Таким чином, законодавством України закріплюється можливість громадян створити, вступити до організації місцевого самоврядування та реалізовувати свої права у взаємовідносинах з поліцією, направлених на підвищення протидії кримінальним правопорушенням та забезпечення охорони правопорядку.

Місцева влада також зацікавлена у партнерстві між поліцією та громадою. Адже мирне співіснування на території конкретної територіальної одиниці та в Україні в цілому $є$ спільною відповідальністю поліції, суспільства та місцевих адміністрацій. Згідно зі ст. 2 Закону України «Про місцеві державні адміністрації», одним 3 основних завдань місцевої влади є забезпечення законності і правопорядку, додержання прав i свобод громадян; виконання державних i регіональних програм соціально-економічного та культурного розвитку, програм охорони довкілля, а в місцях компактного проживання корінних народів і національних меншин - також програм їх національ- 
но-культурного розвитку; взаємодію з органами місцевого самоврядування [11].

Місцева влада відповідає за забезпечення добробуту, освітлення території в темну пору доби, ремонт доріг та пішохідних доріжок, аварійних будинків тощо. Саме тому їхня роль у розвитку партнерських відносин дуже важлива. Місцева влада спільно з мешканцями може визначити небезпечні для людей ділянки в місті, селі, селищі та краще зрозуміти потреби у безпеці. Місцева влада зобов'язана відповідати на запити людей щодо підвищення рівня безпеки конкретними діями, через що довіра до неї зростатиме. Місцева влада може сформувати пріоритети у сфері розвитку міста (території), які важливі для населення, та передбачити ефективний план досягнення цілей. Безпечна територія привабливіша для інвестиційних проєктів, а це дає можливість залучити зовнішні кошти для розбудови міст і селищ. Чим безпечніше місто чи село, тим воно комфортніше для туристів, які забезпечать додатковий дохід для громади [15].

Що стосується форм комунікації партнерства між громадськістю та поліцією, то 3 загальнотеоретичних позицій під формою розуміється зовнішне вираження змісту діяльності, межі конкретних управлінських дій, що здійснюються безпосередньо суб'єктами управління. У юридичній літературі розподіляють форми на правові (встановлені у нормативно-правових актах) та неправові.

Взаємодія правоохоронних органів 3 інститутами громадянського суспільства процесуальної форми поки не отримала. Взаємодію між сторонами не можна віднести до реалізації виконавчої діяльності вона лише забезпечує безпосереднє здійснення повноважень органу, сприяє йому. У той же час така взаємодія не може бути внутрішньоорганізаційною, оскільки здійснюється 3 зовнішніми суб'єктами - 3 інститутами громадянського суспільства.

Таким чином, завдяки залученню людей (наприклад, спільне патрулювання, нагляд за територією і вчасне інформування правоохоронних органів) поліція зможе ефективніше запобігати новим правопорушенням. Як наслідок, поменшає робо- ти, пов'язаної із реагуванням на вчинені правопорушення і розслідуванням скоєних кримінальних правопорушень. Співпраця 3 активними мешканцями дозволить заручитись підтримкою громади і будувати довіру між поліцейськими та мешканцями. Вирішення проблем, які турбують громаду, сприяє формуванню позитивного іміджу поліції. Співпрацюючи з громадою, поліція має можливість підвищувати обізнаність мешканців про свою роботу (наприклад, про межі компетенції поліцейських або про альтернативні шляхи вирішення проблем). А це дозволить у подальшому зменшити навантаження на працівників поліції [15].

Високоефективним досвідом партнерської співпраці органів поліції та інститутів громадянського суспільства на основі спеціалізованих програм мають США, Японія, країни Західної Европи. У цих державах основним принципом діяльності поліції 6 принцип «активного соціального партнерства», що передбачає інтеграцію громадської активності у правоохоронну систему. Громадяни не тільки усвідомлюють свою високу місію виконання громадського обов'язку щодо зміцнення законності і правопорядку, але і мають у своєму розпорядженні серйозні ресурси для здійснення самостійних дій.

Серед колективних форм участі громадян в охороні правопорядку і боротьбі зі злочинністю використовуються:

- створення пунктів по забезпеченню правопорядку і попередження злочинності (Японія);

- формування поліцейського резерву (помічників) (СІІА);

- організація патрулювання громадських місць;

- створення добровільних дружин та інших громадських формувань правоохоронної спрямованості (Білорусія, Великобританія, СШІА, Естонія);

- співпраця з приватними охоронними підприємствами (Перу).

Наприклад, у США формування поліцейського резерву (помічники) з числа осіб громадянських суспільств, добровільно і безоплатно виконують обов'язки щодо забезпечення правопорядку, наділені повноваженнями щодо припинення правопору- 


\section{Теорія, історія держави і права, конституційне право}

шень, забезпечені поліцейської формою, проходять спеціальну підготовку [12]. Великою популярністю в США користуються Народні поліцейські академії, ідея яких народилася у Великобританії. Основна мета таких академій - познайомити населення 3 роботою поліції. Академія служить, у першу чергу, для формування позитивного ставлення населення до поліції і посилення взаємозв’язків між поліцією і громадянами. Особи, які закінчили Народну поліцейську академію, краще розуміють роль і специфіку роботи поліції, більше допомагають поліцейським і швидше йдуть на контакт з ними [12].

Примітний досвід соціального партнерства державно-суспільних інститутів Великобританії в рамках концепції антикримінальної політики «Law and Order» ( «Закон і порядок»). Діяльність у цій сфері є предметом пильної уваги законодавчої, виконавчої, судової влади, преси та соціальних груп, що стежать за співвідношенням відповідності встановлюваного переслідування (санкцій) суспільної небезпеки скоєних протиправних дій. Концепція сприяє формуванню механізму протидії протиправним зазіханням і консолідації суспільної правосвідомості [13].

Для посилення зв'язку з цивільним населенням у більшості британських поліцейських формувань організовані спеціальні підрозділи, у яких підготовлені громадяни на добровільних засадах працюють мінімум чотири години на тиждень.

Незвичайну форму залучення громадськості до забезпечення правопорядку використовують у Данії. Держава ініціювало операцію «Слідопит»: за невелику винагороду пенсіонери регулярно обходять закріплені за ними вулиці, уважно придивляються до машин і обстановці на вулиці, а потім інформують поліцію про стан порядку на конкретній території та мають місце правопорушення [14].

\section{Висновки}

Правоохоронна функція $\epsilon$ найважливішою функцією, в основі якої лежить діяльність держави щодо захисту прав і свобод окремої особи, організацій, держави і суспільства в цілому. У реалізації правоохорон- ної функції сучасної держави беруть участь державні органи, соціально активні громадяни та недержавні організації.

Оновлений варіант взаємодії працівників поліції з різними соціальними групами призведе до позитивних досягнень у подоланні злочинності і підвищення рівня громадської безпеки. Знизиться соціальна напруга в середовищі співробітників правоохоронних органів, підвищиться їх задоволеність своєю працею, покращиться імідж поліції, який у цей час знаходиться на не цілком прийнятному рівні. Підвищиться рівень соціальної активності громадян, ступінь їх залученості в рішенні проблем протидії кримінальним правопорушенням. Покращиться система цивільного контролю за правоохоронною діяльністю, необхідність розширення якого виступає обгрунтованою вимогою сучасного суспільства.

\section{\iтература}

1. Закон України «Про Національну поліцію». Відомості Верховної Ради (ВВР), 2015, № 40-41, ст.379.

2. Крестоцеловальная запись губных старост в 50-е гг. XVI в. // Памятники русского права. - 1952. - Вып. 4. - С. 186-188.

3. Історія держави та права України. Підручник. - У 2-х т. / За ред. В. Я. Тація, А. Й. Рогожина, В. Д. Гончаренка. - Том 1. Кол. авторів: В. Д. Гончаренко, А. Й. Рогожин, О. Д. Святоцький та ін. - К.: Концерн «Видавничий Дім «Ін Юре», 2003. - 484 с.

4. Ожегов С.И., Шведова Н.Ю. Толковый словарь русского языка: 8000 слов и фразеологических выражений. - 4-е изд., М.: Высшая школа, 1993. - С. 485.

5. Значение слова партнёр в социологическом словаре [Әлектронный ресурс]: URL: http:/diclist.ru/slovar/sociologicheskiy/f/ partner.html (дата обращения: 23.08.2021).

6. Социологический энциклопедический словарь / Под ред. Осипова Г.В. - М.: ИНФРА-М, 2000. - С. 234.

7. Кодекс поведения должностных лиц по поддержанию правопорядка. Резолюция 34/169 Генеральной Ассамблеи ООН от 17 декабря 1979 г. URS: https://zakon.rada.gov. ua/laws/show/995_282\#Text (дата звернення 24.08.2021). 
8. Резолюция N 690 (1979) Парламентской ассамблеи Совета Европы «Декларация о полиции» (Страсбург, 8 мая 1979 года) URS: https://zakon.rada.gov.ua/ laws/show/994_803\#Text (дата звернення 24.08.2021).

9. Закон України «Про участь громадян в охороні громадського порядку і державного кордону». (Відомості Верховної Ради України (ВВР), 2000, № 40, ст.338).

10. Закон України «Про місцеве самоврядування в Україні». Відомості Верховної Ради України (ВВР), 1997, № 24, ст.170.

11. Закон України «Про місцеві державні адміністрації». Відомості Верховної Ради України (ВВР), 1999, № 20-21, ст.190.

12. Столичная полиция США: официальный сайт. 2016. - https://www.uscp.gov/ thedepartment/bureaus-and-offices (дата звернення: 24.08.2021).

13. Полиция Великобритании: официальный сайт. 2016. - https://www.police. uk/informationand-advice (дата звернення: 24.08.2021).

14. Полиция Дании: официальный сайт. 2016. - https://www.politi.dk/en/servicemenu/ home (дата звернення: 24.08.2021).

15. Взаємодія поліції та громади. Community Policing. URS: https://ecpl.com.ua/wpcontent/uploads/2017/02/com_pol.pdf (дата звернення 24.08.2021).

\section{POLICE AS PART OF THE COMMUNITY. FORMS OF COMMUNICATION}

One of the main conditions for the successful functioning of any social system, including law enforcement, is to combine the efforts and capabilities of its components to achieve common goals. Every state has a holistic system that has many integration properties. Designed to ensure a certain settlement and orderliness of social relations, the state itself must have the quality of unity, consist of a set of state bodies in a strictly defined dependence of its constituent components with its inherent internal (systemic) and external (functional connections), relationships and interactions. Interaction as a manifestation of the integrity of any system is organically inherent in it, due to which it is objective in nature.

Studying the history and current state of participation of law enforcement agencies as part of the community, it can be stated that one of the most important tools of law enforcement is interaction with the population. The purpose of law enforcement agencies is focused on controlling a specific territory, combating criminal offenses and ensuring the protection of law and order, to achieve these goals it is necessary to take into account the needs of citizens. Such a question requires an individual approach, on the one hand, and on the other - the willingness of the public to take part of the responsibility focused on the overall quality of life. This creates a partnership between the police and the public, which is based on trust on both sides.

Keywords: police, partnership, society, interaction, public, offense, counteraction. 